\title{
PENGARUH AROMATERAPI LAVENDER TERHADAP DEPRESI PADA LANSIA DI WILAYAH KERJA PUSKESMAS CITEUREUP KOTA CIMAHI 2015
}

\author{
Nadirawati ${ }^{1}$ \\ ${ }^{1}$ Dosen STIKES UNJANI BANDUNG
}

\begin{abstract}
ABSTRAK
Gangguan mental yang paling sering ditemukan pada lansia adalah depresi. Prevalensi depresi pada lansia ditingkat pelayanan primer sekitar $5-17 \%$. Depresi yang dialami oleh pasien bisa berupa menurunnya minat dan kemampuan dalam melakukan aktifitas seharisehari. Salah satu upaya non farmakologis yang dipercaya dapat mengatasi depresi adalah aromaterapi. Aromaterapi merupakan salah satu metode non farmakologis relaksasi yang dapat memberikan efek relaksasi, salah satunya adalah lavender. Tujuan penelitian untuk mengetahui pengaruh aromaterapi lavender terhadap depresi pada Lansia. Penelitian ini menggunakan desain pre-eksperimental dengan bentuk rancangan one group pretestposttest design. Sampel dalam penelitian ini sebanyak 35 orang dengan teknik purposive sampling dan analisa data dengan uji Wilcoxon Signed Rank Test. Hasil penelitian memperlihatkan bahwa rata-rata skor depresi sebelum diberikan Aromaterapi Lavender adalah 10.69 sedangkan rata-rata skor depresi setelah Aromaterapi Lavender adalah 5,54. Setelah dilakukan uji statistic didapatkan ada pengaruh Aromaterapi Lavender terhadap lansia yang mengalami depresi di Wilayah Kerja Puskesmas Citeureup KotaCimahi, ( $\rho$ value 0,$000 ; \alpha 0,05$ ). Dari hasil penelitian tersebut disarankan bagi Perawat Pukesmas untuk meningkatkan kemampuan dan pengetahuan penanganan pasien depresi baik bersifat farmakologis maupun dengan non farmakologis dan juga melakukan sosialisasi tentang Aromaterapi Lavender pada masyarakat, sebagai salah satu tindakan untuk mengatasi masalah lansia yang mengalami depresi.
\end{abstract}

Kata kunci : Aromaterapi, Depresi, Lavender, Lansia

\begin{abstract}
Mental disorders which most often founded on Elderly is depression. Depression prevalence on Elderly at primary service is about 5-17\%. Depression which can be happen to Elderly like proclivity decreasing, the capability to do daily activity. One non pharmacologys effort that believed to overcome depression is aromatheraphy. Aromatheraphy is one methode of relaxation non pharmacologys that can give relaxation effect, one is from Lavender. The aim of this research is to know the influence of lavender aromatheraphy to the Elderly depression. This research use pre-eksperimental design with one group pretest-posttest design plan. The sample of this research about 35 respondent with purposive sampling technique dan Wilcoxon Signed Rank Test analysis. The result of this reserach show that in average depression score before Lavender aromatheraphy intervension is 10,69 meanwhile the average of depression score after the intervension is 5,54. After doing the statistic test, established the conclusion that the lavender aromatheraphy influence the Elderly who has depression at Citeureup Public Health Centre Cimahi City, ( $p$ value 0,000; $a$ 0,05). Researches is recommended to the Public Health Centre Nurse to increase the knowledge and capability in handling depression patient which pharmacologys or non pharmacologys. Other recommendation is to do sosialization about Lavender aromatheraphy to the community, as an alternatives action to overcome the depression which happened to Elderly.
\end{abstract}

Keyword : Aromatheraphy ; Depression ; Lavender ; Elderly 


\section{PENDAHULUAN}

Secara umum kondisi fisik seseorang yang telah memasuki masa lansia mengalami perubahan yang pada umumnya mengarah pada kemunduran kesehatan fisik dan psikis. Secara umum lansia yang mengalami kemunduran fisik, juga akan mempengaruhi psikologis yang menyebabkan tingginya angka depresi pada lansia (Stanley \& Beare, 2006). Prevalensi depresi pada lansia ditingkat pelayanan primer sekitar $5-17 \%$. Sementara depresi lansia pada tingkat pelayanan Rumah (Homecare) adalah $35 \%$. Penelitian di Amerika menunjukan kira-kira $10-15 \%$ dari semua lansia yang berusia lebih dari 65 tahun yang ditinggal di komunitas menunjukkan gejala depresi (Stanley, 2006). Data prevalensi pada lansia di Indonesia cukup tinggi. Kejadian di ruang akut geriatrik sebanyak $76,3 \%$ dengan proporsi pasien yang mengalami depresi ringan adalah $44,1 \%$, depresi sedang sebanyak $18 \%$, depresi berat sebanyak $10,8 \%$ dan depresi sangat berat sebanyak $3,2 \%$ (Syamsuddin, 2006).

Depresi merupakan suatu masa terganggunya fungsi manusia yang berkaitan dengan alam perasaan yang sedih dan gejala penyertanya. Depresi yang dialami pasien bisa berupa menurunnya minat dan kemampuan dalam melakukan aktifitas sehari-sehari, munculnya gangguan emosional (Azizah, 2011). Keperawatan sebagai profesi turut serta mengusahakan tercapainya kesejahteraan fisik, mental dan spiritual klien. Salah satu fungsi independen yang merupakan fungsi mandiri dan tidak tergantung pada petugas medis lain, dimana perawat dalam melaksanakan tugasnya secara mandiri dengan keputusannya sendiri dalam melakukan tindakan dalam rangka pemenuhan kebutuhan dasar manusia (Perez, 2003).

Sebagai pemberi asuhan keperawatan, maka seorang perawat harus mengembangkan berbagai intervensi untuk mengatasi berbagai penyakit khususnya depresi pada lansia, salah satunya adalah pengembangan terapi komplementer. Aromaterapi merupakan bagian dari pengobatan herbal, yang merupakan asal mula pengobatan konvensional. Aromaterapi merupakan salah satu terapi komplementer yang dapat digunakan untuk mengatasi depresi. Aromaterapi memiliki efek menenangkan atau rileks untuk beberapa gangguan misalnya mengurangi kecemasan, depresi, ketegangan dan insomnia.

Aromaterapi terdiri dari minyak tumbuhan atau minyak esensial untuk meningkatkan kesejahteraan psikologis. Aroma terapi dianjurkan untuk orang yang memiliki masalah kecemasan, untuk menenangkan tubuh, pikiran dan saraf. Wewangian seperti lavender, chamomile dan vanili memiliki efek menenangkan. Aroma yang paling populer adalah Lavender. Lavender digunakan terutama untuk relaksasi, untuk mengurangi susah tidur, kecemasan, dan depresi (Cuncic, 2012). Lavender memiliki kandungan linalool asetatlinalyl yang merupakan bahan aktif utama pada minyak lavender, terbukti menghambat pengikatan glutamate di otak, menghambat pelepasan asetilkolin dan mempengaruhi konduktasi ion dalam neuron. Linalool asetat linalyl dapat menunjukkan efek relaksasi, sehingga tidak ada kontraindikasi dan efek samping, atau interaksi obat pada lavender (Appleton, 2012). Yarnel and Abascal (2004) mengatakan bahwa penggunaan lavender dikatakan dapat membantu memberikan ketenangan, mengurangi sakit kepala, anti mikroba, anti serangga, penyembuhan luka ringan, anti depresan dan anti septik.

Berdasarkan studi pendahuluan yang telah dilakukan pada Bulan Juni 2015 terhadap 7 orang lansia di RW 04 dan 5 Wilayah Kerja Puskesmas Citeureup kelurahan Cipageran mengalami mudah mengalami lelah, sulit tidur, suka menyendiri dan mudah tersinggung. Cara mengatasi depresi yang mereka lakukan biasanya rekreasi, melakukan pekerjaan rumah tangga dan menghibur diri sendiri dengan menonton televisi. Dari semua yang diwawancara tidak ada yang menggunakan aromaterapi. Tujuan Penelitian adalah untuk mengetahui pengaruh 
aromaterapi lavender terhadap depresi pada lansia di wilayah kerja Puskesmas Citeureup Cimahi. Tujuan khususnya: ingin mengetahui rerata depresi sebelum dilakukan aromaterapi lavender pada lansia ; ingin mengetahui

\section{METODE PENELITIAN}

Rancangan penelitian yang digunakan adalah pre-eksperimental designs. Pendekatan yang digunakan adalah One Group Pretest Posttest design. Pengambilan sampel dilakukan dengan teknik Purposive Sampling. Besar sampel pada penelitian ini sebanyak 35 responden. Peneliti melakukan pengkajian Depresi dengan menggunakan skala Beck sebelum diberikan aromaterapi. Peneliti memberikan aromaterapi 3 tetes selama kurang lebih 10-20 menit pada setiap pasien, dengan jenis aromaterapi lavender, caranya dengan pembakar minyak yang menggunakan tungku dan terdapat lilin kecil dalam tungku. Selama pemberian aromaterapi pasien bernapas biasa dan tidak melakukan aktivitas lain. Setelah itu depresi diukur lagi dengan cara yang sama, kemudian hasil dari pengkajian dicatat dan didokumentasikan pada data perkembangan depresi dalam data penelitian responden. Hal ini akan dilakukan kurang lebih selama 1 minggu.

Pengolahan data dilakukan dengan Analisa Univariat dan Bivariat. Sebelum rerata depresi sesudah dilakukan aromaterapi lavender pada lansia; ingin menganalisis pengaruh aromaterapi lavender terhadap depresi Pada lansia Di Wilayah Kerja Puskesmas Citeureup Cimahi.

melakukan analisis bivariat terlebih dahulu melakukan uji normalitas data dan uji homogenitas varian. Selanjutnya dilakukan analisis bivariat untuk mengetahui skor depresi sebelum dan sesudah dilakukan intervensi dengan menggunakan uji beda dua mean dependen. Pada hasil uji normalitas data yang menunjukkan data berdistribusi normal maka analisis bivariat yang digunakan adalah uji parametrik dengan jenis uji beda dua mean dependen (paired $t$ test).. Pada hasil uji normalitas data yang menunjukkan data tidak berdistribusi normal maka analisis bivariat yang digunakan adalah uji nonparametrik dengan jenis uji Wilcoxon.

Berdasarkan ANA (1985) dalam Pollit \& Beck (2005) terdapat 5 kode etik penelitian dalam keperawatan, yaitu: Confidentiality (Kerahasiaan); Keadilan dan inklusivitas (respect for justice and inclusiveness); Memperhitungkan manfaat dan kerugian yang ditimbulkan (balancing harms and benefits). Penelitian dilakukan pada Bulan Desember 2015 - Februari 2016.

\section{HASILPENELITIAN}

Tabel 1. Rerata depresi lansia sebelum \& setelah diberikan Aromaterapi Lavender

\begin{tabular}{ccccc}
\hline \multirow{2}{*}{ Var } & \multirow{2}{*}{ Mean Depresi } & \multirow{2}{*}{ SD } & \multicolumn{2}{c}{$95 \% \mathrm{Cl}$} \\
\cline { 3 - 5 } & & & Min & Max \\
\hline Pre & 10.69 & 2.55 & 7 & 17 \\
\hline Post & 5.54 & 1.40 & 3 & 8 \\
\hline
\end{tabular}

Pada tabel 1 di atas memperlihatkan bahwa rata-rata skor depresi sebelum Aromaterapi Lavender adalah 10,69 dengan standar deviasi 2,55 sedangkan setelah Aromaterapi Lavender adalah 5,54 dengan standar deviasi 1,40. Kondisi tersebut masih termasuk ke dalam kriteria depresi. 
Nadirawati, STIKes UNJANI Bandung: Aromaterapi, Depresi, Lavender, Lansia

Tabel 2. Pengaruh Aromaterapi Lavender terhadap depresi lansia

\begin{tabular}{|c|c|c|c|c|c|c|}
\hline \multirow{2}{*}{ Var } & \multirow{2}{*}{ Mean Depresi } & \multirow{2}{*}{$\begin{array}{l}\text { Perbedaan } \\
\text { Mean }\end{array}$} & \multirow{2}{*}{ SD } & \multicolumn{2}{|c|}{$95 \% \mathrm{Cl}$} & \multirow{2}{*}{ P Value } \\
\hline & & & & Min & Max & \\
\hline Pre & 10.69 & \multirow{2}{*}{5.15} & \multirow{2}{*}{1.15} & 7 & 17 & \multirow{2}{*}{0.000} \\
\hline Post & 5.54 & & & 3 & 8 & \\
\hline
\end{tabular}

Pada tabel 2 di atas memperlihatkan bahwa rata-rata skor depresi sebelum diberikan Aromaterapi Lavender adalah 10,69 sedangkan rata-rata skor depresi setelah Aromaterapi Lavender adalah 5,54 ada perbedaan mean sebesar 5,15 dengan

\section{PEMBAHASAN}

Depresi merupakan suatu perasaan sedih dan pesimis yang berhubungan dengan suatu penderitaan(Nugroho,2008). Depresi dapat disebabkan berbagai faktor, yaitu faktor biologis, sosial,dan psikologis. Faktor biologis yang menyebabkan depresi yaitu berbagai penyakit fisik dan obatobatan yang digunakan untuk mengatasinya. Faktor sosial yang menyebabkan depresi yaitu kurangnya interaksi sosial, kesepian, berkabung, dan kemiskinan, sedangkan faktor psikologis berupa rasa kurang percaya diri, kurangnya keakraban, dan ketidakberdayaan akibat penyakit kronis (Kaplan dan Sadock, 2010).

Secara fisiologis, pada kondisi depresi tubuh akan mengaktifasi hipotalamus yang selanjutnya mengendalikan 2 sistem neuroendokrin yaitu sistem simpatis dan sistem korteks adrenal. Sistem saraf simpatis memberi sinyal ke medulla adrenal untuk melepaskan epinefrin dan norepinefrin ke aliran darah. Sistem korteks adrenal di aktivasi jika hipotalamus mensekresikan suatu zat kimia yang bekerja pada kelenjar hipofisis yang terletak tepat dibawah hipotalamus.

Pada tabel 3 di atas memperlihatkan bahwa rata-rata skor depresi sebelum diberikan Aromaterapi Lavender adalah 10.69 sedangkan rata-rata skor depresi setelah Aromaterapi Lavender adalah 5.54, ada perbedaan mean sebesar 5.15 dengan standar deviasi 1,15. Setelah dilakukan uji statistik didapatkan ada pengaruh Aromaterapi Lavender terhadap lansia yang mengalami depresi di Wilayah Kerja Puskesmas Citeureup Kota Cimahi ( $\rho=$ value 0,$000 ; \alpha=0,05$ ).

standar deviasi 1,15. Setelah dilakukan uji statistik didapatkan ada pengaruh Aromaterapi Lavender terhadap lansia yang mengalami depresi di Wilayah Kerja Puskesmas Citeureup Kota Cimahi ( $\rho$-value $=0,000 ; \alpha=0,05)$.

Rangsangan bau berpengaruh secara langsung pada otak. Proses terapi umumnya diawali dengan penciuman wewangian minyak essensial yang dapat langsung mencapai paru-paru dan sistem sirkulasi darah begitu aroma tercium, sehingga mudah terserap masuk dalam tubuh manusia. Sifat senyawa pada minyak esensial mudah larut dalam lemak, walaupun begitu, efek terbesar dari terapi wewangian ini terjadi di bagian otak, melalui sistem saraf olfaktorius yang berhubungan dengan indera penciuman yang berkaitan langsung dengan rangsangan bau. Bau yang merupakan stimulan ingatan yang sangat kuat, secara spontan memberikan tanda-tanda emosi yang disebabkan karena keunikan dari sistem penciuman yang berhubungan langsung dengan sistem limbik dan emosi kita (Primadiati, 2002)

Mekanisme kerja perawatan aromaterapi di dalam tubuh manusia berlangsung melalui 2 sistem fisiologis, yaitu sistem sirkulasi tubuh dan sistem penciuman. Bila diminum atau dioleskan pada permukaan kulit, minyak esensial akan diserap tubuh, yang selanjutnya akan dibawa oleh sistem sirkulasi darah maupun sirkulasi limfatik melalui 
proses pencernaan dan penyerapan kulit oleh pembuluh pembuluh kapiler. Selanjutnya, pembuluh kapiler mengantarnya ke susunan saraf pusat dan oleh otak akan dikirim berupa pesan ke organ tubuh yang mengalami gangguan atau ketidakseimbangan (Primadiati, 2002). Sistem limbik adalah bagian dari otak yang dikaitkan dengan suasana hati, emosi, memori, dan belajar kita. Semua bau yang mencapai sistem limbik memiliki pengaruh langsung pada suasana hati kita (Sharma, 2009) sehingga menyebabkan rasa nyaman dan tenang, hal ini memungkinkan terjadinya penurunan skor depresi pada lansia.

Hal tersebut diatas juga didukung oleh penelitian oleh Dewi (2012) bahwa minyak lavender dengan kandungan linaloolnya adalah salah satu minyak aromaterapi yang banyak digunakan saat ini, baik secara inhalasi atau teknik pemijatan pada kulit. Aromaterapi yang digunakan melalui cara inhalasi akan masuk ke sistem limbic dimana aroma akan diproses sehingga kita dapat mencium baunya. Pada saat kita menghirup suatu aroma, komponen kimianya akan masuk ke bulbus olfactory, kemudian ke limbic sistem pada otak. Limbic adalah struktur bagian dalam dari otak yang berbentuk seperti cincin yang terletak di bawah cortex cerebral.

Sistem limbic sebagai pusat nyeri, senang, marah, takut, depresi, dan berbagai emosi lainnya. Amygdala sebagai bagian dari sistem limbic bertanggung jawab atas respon emosi kita terhadap aroma. Hipocampus bertanggung jawab atas memori dan

\section{KESIMPULAN}

Rata-rata skor depresi sebelum Aromaterapi Lavender adalah 10,69. Ratarata skor depresi setelah Aromaterapi Lavender adalah 5,54. Secara statistik ada pengaruh Aromaterapi Lavender terhadap lansia yang mengalami depresi di Wilayah Kerja Puskesmas Citeureup Kota Cimahi ( $\rho$-Value $=0,000 ; \quad \alpha=0,05)$. Dengan hasil tersebut diharapkan perawat dapat meningkatkan kemampuan dan pengenalan terhadap bau juga tempat dimana bahan kimia pada aromaterapi merangsang gudang-gudang penyimpanan memori otak kita terhadap pengenalan baubauan.

Minyak lavender adalah salah satu aromaterapi yang terkenal memiliki efek menenangkan. Menurut penelitian yang dilakukan terhadap tikus, minyak lavender memiliki efek sedasi yang cukup baik dan dapat menurunkan aktivitas motorik mencapai $78 \%$, sehingga sering digunakan untuk manajemen stres. Beberapa tetes minyak lavender dapat membantu menanggulangi insomnia, memperbaiki mood seseorang, dan memberikan efek relaksasi. Penelitian lain yang dilakukan terhadap manusia mengenai efek aromaterapi lavender untuk relaksasi, kecemasan, mood, depresi dan kewaspadaan pada aktivitas EEG menunjukkan terjadinya penurunan kecemasan, perbaikan mood, dan terjadi peningkatan kekuatan gelombang alpha dan beta pada EEG yang menunjukkan peningkatan relaksasi. Didapatkan pula hasil yaitu terjadi peningkatan secara signifikan dari kekuatan gelombang alpha di daerah frontal, yang menunjukkan terjadinya peningkatan rasa kantuk sehingga dapat menurunkan skala depresi. Berdasarkan hasil penelitian diatas maka aromaterapi lavender dapat digunakan sebagai terapi pelengkap yang memberikan efek mengatasi depresi pada lansia. Penggunaan aromaterapi sebagai terapi pelengkap harus diikuti penggunaan terapi utama yang telah diberikan atau menggabungkan dengan terapi pelengkap lainnya.

pengetahuan dalam penanganan pasien depresi baik bersifat farmakologis maupun dengan non farmakologis, seperti melakukan sosialisasi tentang Aromaterapi Lavender pada masyarakat, sehingga masyarakat dapat mempertimbangkan Aromaterapi Lavender sebagai salah satu tindakan untuk mengatasi masalah lansia yang mengalami depresi. 


\section{DAFTAR PUSTAKA}

Arikunto, S., 2006. Prosedur penelitian: suatu pendekatan praktik. Jakarta: Rineka Cipta.

Azizah, M.L., 2011. Keperawatan Lanjut Usia. Yogyakarta: Graha IImu.

Appleton, J., 2012. Minyak Lavender untuk Kecemasan dan Depresi.

Azwar, 2004. Upaya Menata Pengobatan Alternatif, diperoleh dari www.kompas. com pada tanggal 02 oktober 2015

Badan Pusat Statistik, 2010. Data Statistik Indonesia. Available diakses dari: http://demografi.bps.go.id pada tanggal 02 Oktober 2015

Cuncic, A., 2012. Lavender Manfaat bagi Kecemasan. Diunduh dari: http://socialanxietydisorder.about.com pada tanggal 20 Oktober 2015.

Dahlan, M.S. 2008. Statistik untuk kedokteran dan kesehatan. Jakarta: Salemba Medika , 2008. Langkah-langkah membuat proposal penelitian bidang kedokteran dan kesehatan. Jakarta: Salemba Medika.

, 2008. Besar sampel dalam penelitian kedokteran dan kesehatan. Jakarta: Salemba Medika

Darmojo,R.B. dan Martono, H., 2004. Geriatri. Jakarta: FK UI.

Depkes, 2006. Pedoman Penyelenggaraan Keperawatan Keluarga. Diakses dari www.hukor.depkes.go.id pada tanggal 19 April 2015

Dewi, 2012. Aromaterapi Lavender Sebagai Media Relaksasi, diunduh dari http://www.jurnal.unud.ac.id diakses tanggal 28 Oktober 2015.

Evidence-Based Complementary and Alternative Medicine, 2012. The Effect of Aromatherapy Abdominal Massage on Alleviating Menstrual Pain in Nursing Students. Diunduh dari www.dx.doi.org diakses tanggal 20 Oktober 2015

Ermiati, et al., 2010. Pengaruh Aromatherapy Terhadap Nyeri Haid Primerdiakses dari www.unpad. ac.id diakses tanggal 20 Oktober 2015
Hartanto, D.A., 2010. herbal-lavender from : Diunduh http://health.detik.com diakses tanggal 20 Oktober 2015

Hawari, D, 2006. Manajemen stress, cemas, dan depresi. Jakarta: Gaya Baru

Hastono, S.P., 2007. Analisis data kesehatan. Depok: FKM UI.

Indonesia Sehat. (2010). Pustaka kesehatan populer. Jakarta: Ensiklopedia

Jaelani, 2009. Aromaterapi. Jakarta: Pustaka Populer Obor.

Kane, 2005. Memahami Penyakit Lansia Jakarta: Erlangga.

Kemenkes, 2013. Riset Kesehatan Dasar: Riskesdas. Jakarta: Balitbangkes Kementrian Kesehatan RI

Kaplan, H.I \& Sadock, B.J. 2010. Sinopsis Psikiatri. Bina Rupa Aksara

Kunstler, et al., 2004. Aromatherapy and Hand Massage: Therapeutic Recreation Interventions for Pain Management, diperoleh dari http://findarticles.com pada 25 Oktober 2015

Lesler, Z.C., 2001. Comprehensive Geriatric Assessment. USA: Mc Graw Hill Companies

Notoatmodjo, S., 2007. Pengantar pendidikan dan perilaku kesehatan. Yogyakarta: Andi Offset.

Perez, C. 2003. Clinical Aromatherapy Part I: An Introduction Into Nursing Practice,diperoleh pada 04 Oktober 2015 dari http://ons.metapress.com

Primadiati, R. 2002. Aromaterapi; Perawatan Alami Untuk Sehat dan Cantik. Jakarta: Gramedia Pustaka Utama.

Polit, D.F. \& Beck, C.T., 2004. Principles and Methods. $7^{\text {th }}$ ed. Philadelphia: Lippincott Williams \& Wilkins.

Polit, D.F. \& Hungler, B.P., 2001. Nursing Research: Principles and Methods. $6^{\text {th }}$ ed. Philadelphia: Lippincott Williams \& Wilkins.

Samsuddin, 2006. Depresi Pada Lansia. diunduh dari http://www.depsos.go.id pada tangal 20 Oktober 2015

Sabri, L., Hastono, S.P., 2008. Statistik kesehatan. Jakarta: Raja Grafindo Persada. 
Sari, 2012. Gambaran tingkat depresi pada lanjut usia di panti sosial tresna Werdha Budi Mulia di Jakarta Timur. Diakses dari http://lib.ui.ac.id pada tanggal 10 November 2015.

Stanley, M. and Beare, G.P., 2006. Buku Ajar Keperawatan Gerontik. Edisi 2. Jakarta:EGC

Snyder, M. and Lindquist, R., 2002. Complementary Alternative Therapies In Nursing. New York: Springer Publishing Company, Inc.

Sharma, S., 2009. Aroma Terapi. Tangerang: Karisma

Sihotang, 2009. Pengaruh Aromaterapi Lavender Terhadap Perubahan TD, HR,
RR Ibu Kalal Persalinan. Diakses dari http://www.repository.usu.ac.id diakses pada tanggal 20 Oktober 2015 Yosep, I., 2009. Keperawatan Jiwa. Edisi Revisi. Bandung:Refika Aditama

Yudistira, 2011. Efektivitas teknik relaksasi napas dalam terhadap penurunan tingkat nyeri. Cimahi: Stikes Jenderal Achmad Yani Cimah.

Yustin, 2011. Pengaruh terapi wewangian minyak esensial bunga mawar dengan cara inhalasi terhadap tingkat kecemasan pada pasien Pre Opp, Skripsi, Padang, http://www.repository.unand.ac.id. diakses tanggal 20 Oktober 2015 